\title{
Does Patrimonialism Hinder the Simplification of Bureaucracy Policy in Indonesia?
}

\author{
Sait Abdullah ${ }^{1}$ \\ \{sait@poltek.stialanbandung.ac.id\} \\ ${ }^{1}$ Polytechnic of STIA LAN Bandung
}

\begin{abstract}
The Jokowi government's policy to simplify structural positions of echelon III and IV in order to speed up the decision-making process and increase the efficiency and effectiveness of the bureaucracy and public services to the community needs to be given a thumbs up. This re-echelonering policy has been targeted for more agile and adaptable bureaucracy in facing the development of information and technology. However, amid this new breakthrough, our bureaucracy has long lived side by side with the structure of patrimonialism as a legacy of feudalism which is deeply rooted in Indonesian society. This patrimonial structure has long penetrated and undermined the body of the bureaucracy and caused a pattern of power relations in the form of dependency relationships between leaders and subordinates. The question is how the new policy face this situation? The paper discusses the dimensions of the structure of patrimonialism that has long been prevalent in our bureaucracy and how to propose some strategic steps to minimize and overcome the patrimonial structure in the Indonesia bureaucracy
\end{abstract}

Keywords: Patrimonialism; simplification of bureaucracy; policy.

\section{Introduction}

This article discusses the popular policy regarding the public administration reform in the Jokowi government. The recent Jokowi government's policy to cut structural positions of echelon III and IV in order to speed up the decision-making process and increase the efficiency and effectiveness of the bureaucracy and public services to the community needs to be given a thumbs up. This echelonering policy has been followed by several ministries such as the Ministry of Finance led by Sri Mulayani and followed by the Ministry of State Apparatus Empowerment and Bureaucratic Reform (Kemenpan RB) led by Tjahjo Kumolo and several ministries including the national Institute of Public Administration.

It will not be long before the beginning of 2021, this policy will be followed by all ministries, non-ministries institutions and local governments to simplify their bureaucracy so that it is leaner, more agile and adaptable to the development of information and technology. Finally, besides stretching functional positions that value expertise more, President Jokowi instructed the Ministry of Administrative Reform to immediately replace these echelons III and IV officials with artificial 
intelligence in the form of robots and artificial intelligent that will help the performance of echelon I and II officials. Jokowi's policy is a new breakthrough that will change the face of Jokowi's government and at the same time this policy causes disruption, turbulence and great panic in the bureaucracy in Indonesia.

However, it should be noted that in the midst of this new breakthrough, we need to know together that there is a great danger that lurks in the Jokowi government's new policy. Our bureaucracy has long lived side by side with the structure of patrimonialism as a legacy of feudalism which is deeply rooted in Indonesian society. This patrimonial structure has long penetrated and undermined the body of the bureaucracy and caused a pattern of power relations in the form of dependency relationships between leaders and subordinates. The principle of this dependency relation applies economically and politically where subordinates expect the distribution of social status in the form of public positions from the leader or superior.

In return, the leader or supervisor expects loyal support which will ultimately perpetuate the status quo of his position as the leader of the organization. This structure of patrimonialism has long lived in our bureaucracy and has penetrated into a culture that bureaucratic officials are aware of or not and is very dangerous for the Jokowi government's commitment to make a clean and professional government. This patrimonial structure will undermine the sense of justice and injure the rights of the State Civil Apparatus (ASN) to have a fair career in the bureaucracy. In order to complement the efforts made by Jokowi's new government in this second period, the author tries to explore the dimensions of the structure of patrimonialism that has long been prevalent in our bureaucracy. So that the questions that will be address in this paper is that does the patrimonialism hinder the simplification of bureaucracy? And how to overcome or minimize the impact of patrimonial culture to the performance of bureaucracy?

\section{The concept of patrimonialism}

Etymologically, the term patrimonialism comes from the typological theory of authority type written by European sociologist, Max Weber, where this social structure is rooted in traditional domination based on the loyalty that individuals get from their traditional status (Gerth and Wright Mills 1977) [1]. The structure of patrimonialism was further developed by political experts and scientists to characterize the social relations of power between the state and society based on the personal use of power. Furthermore, patrimonial according to the Big Indonesian Dictionary is defined as about legacy.

In the concept of anthropology, patrimonial comes from the word patir and genetically comes from the word patris which means father. The position of this father figure will literally foster a 'relationship between a father and his children' (followers) (Brown 1994 [2], see also Sukitman, Tri Mardika Alam, 2015 [3]). In this personal bond, subordinates have little or no access to power other than through their dependence on their Father. The father provides protection as well as economic distribution and high social status in return for his subordinates offering loyalty and support to the father.

In the pattern of organizational relationships, patrimonial relations in this organization are formed as a pattern of reciprocal relationships between those in power providing physical facilities, infrastructure and protection while the client provides support in the form of loyalty, service and other political support (Sukitman, Tri Mardika Alam, 2015). In line with Brown (1994), James Scott 
(1972) [4], describes that this patrimonial structure is manifested in the form of a patron-client relationship where there is an attachment relationship between the master (patron) and his servant (client). This relationship occurs because of differences in the distribution of power where the patron has wider access than the client.

However, to maintain the continuity of this personal exchange relationship between the patron and the client, the patron will try to maintain the status quo by creating a relationship of dependence with the client, where the client gains material benefits and social status and access to power through the patron. Emerson (1983) elaborates that patrimonialism refers to the centralization of power personally to individuals through the exchange of benefits in the form of social and economic status [5]. The ruler tries to maintain this exchange relationship by distributing the resources he has in the hope that parties with an interest in the ruler provide political support to the ruler. This pattern of patron-client relationships is emphasized in the research of Dwiyanto (2001) which concludes that bureaucratic culture in Indonesia is strongly influenced by paternalistic patterns born of Javanese culture, which places the dominant role of superiors or leaders in the bureaucracy in providing protection to their subordinates [6].

This Javanese culture contains the principle of the relationship pattern between 'father' and 'child' where the father has the role to provide protection for the social, material, spiritual and emotional needs of the child. In return for the protection provided by the father, the child provides loyal support and voluntarily fulfills the father's orders. If translated in the pattern of relationships in the bureaucracy, this pattern of relationships is very centralized where the subordinate must obey all orders and orders from superiors for the personal interests of superiors. To strengthen the argument about how thick the structure of patrimonialism in the bureaucracy in Indonesia is, scientific evidence (evidence) has been carried out by researchers in the bureaucracy in Indonesia.

For instance, the findings of Wasito Raharjo Jati (2012) regarding the pattern of patrimonialism in the bureaucracy in the Yogyakarta DIY Government stated that "the Sultanate of Yogyakarta and the Kadipaten Pakualam still exist in the current republican era because they run a hybrid bureaucratic system where the bureaucracy actually carries out traditional functions by maintaining patrimonial power relations in addition to uphold the values of a modern bureaucracy" [7]. According to Wasito Raharjo, 'abdi dalem keprajan' in the form of a modern bureaucracy can be said to have a dual role (dual system), namely as a techno-administrative force as well as a symbolizing power of real royal patrimonialism.

Furthermore, a survey of Public Service Performance in Licensing and Land Affairs agencies in several provincial governments such as in West Sumatra, South Sulawesi and DIY concluded that there is a pattern of superior-subordinate dependence in public services. The survey stated that $44 \%$ of service officers put the interests of their superiors first in providing services (Dwiyanto,2001).

\section{Methodology}

To gather data and information this paper uses qualitative descriptive approach by utilizing literature studies and relevant research in the field and using secondary data that is collected from books, journal, government's reports, social media. These data and information are useful for the researchers in analyzing the pattern of patrimonialism in Indonesia bureaucracy amid the simplification of the Indonesian bureaucracy. 


\section{Discussion}

Responding to this phenomenon, the Jokowi government needs to pay attention to bureaucracy which has two sides that are contradictory to each other, namely first is as a modern bureaucracy, which focuses on aspects of work performance, rationality and professionalism. Second, bureaucracy is also very thick with the cultural structure of patrimonialism which prioritizes aspects of patrimonial ties that characterize a traditional bureaucracy that considers bureaucracy as a personal matter in patron-client ties. There have been several studies that have examined how the pattern of patron-client or patrimonialism bureaucracy is indeed very thick in our country.

For example, research conducted by Reastyawati (2015) concluded that the political pattern of patrimonialism has become so ingrained that it looks thick and takes the form of kinship politics from the national to the local level [8]. By taking a sample of bureaucratic research at the local level, Raestyawati stated that the political pattern of kinship based on family closeness was very strong in Sumberejo Village, Kerjo sub-district, Karang Anyar district (2015). Other researchers also found cases that the merit system in staffing transfers at the Regional Personnel Agency of North Halmahera Regency was constrained by familial political factors (Tawaris, et al, 2018) [9].

Similar research was also conducted by the Rusliandy research team. et. Al (2019) concluded that the implementation of the merit system was constrained by the personal politics of proximity that puts the loyalty aspect of subordinates to superiors at the PUPR Office of Bogor Regency [10]. The mobilization of bureaucratic officials and patrimonial political patterns also occurred in the direct election of regional heads in West Sumba Regency (Umbu Mete, 2018). This mobilization of State Civil Apparatus occurs through the traditional Kedde mechanism which requires reciprocal politics between the patron who provides animal assistance for the traditional death ceremony in the hope that the client returns it in the form of political support in winning the patron in the regional head election in West Sumba Regency [11].

Therefore, observing this phenomenon, the author argues that the Jokowi government will be more successful and more effective in carrying out bureaucratic reform, if the Jokowi government does not only organize the bureaucracy at the level of the formal organizational structure by cutting echelon III and IV positions which are felt to be ineffective and wasteful. state finances. More importantly, in order not to be biased, the Jokowi government must also focus on reforming the bureaucracy as a whole, including fixing the octopus, the patrimonial cultural structure of the bureaucracy, which is very bad and has been thriving for a long time in the bureaucracy in Indonesia.

The Jokowi government must take strategic steps to minimize and even eradicate the octopus of the patrimonial structure in the bureaucracy in three ways, namely: First, fixing the merit system in the bureaucracy. This merit system will replace the patron-client pattern that relies on the path of loyalty, like and dislike and obedience to superiors with one's work performance pattern. This merit system is emphasized by enforcing all government agencies, both central and regional, to develop a career path map for the State Civil Apparatus (ASN).

For the smooth enforcement of this rule, it is hoped that all State Civil Apparatus in the bureaucracy have the same rights in accordance with the applicable laws and regulations. Prior to 
the implementation of this bureaucratic simplification, in order to realize this merit system, the government had first enacted Law Number 5 of 2014 concerning the State Civil Apparatus [12] and its derivatives, namely Government Regulation Number 11 of 2017 concerning Civil Servant Management [13]. These governments' regulations have to become standard to the implementation of merit system policy in bureaucracy.

Second, the Jokowi government must oblige all government agencies to draw up regulations on the State Civil Apparatus' code of ethics and establish an internal ethics committee/board that involves an independent party from the State Civil Apparatus Commission (KASN, a non-structural institution assigned the task of supervising the implementation of the ASN code of ethics in government institutions, both central and regional). The code of ethics and the internal ethics committee/board will work intensively in dealing with complaints of abuse of power by high officials. The government's obligation to establish and manage this code of ethics is stated in the Government Regulation of the Republic of Indonesia Number 42 of 2004 concerning the Guidance of Corps Spirit and the Code of Ethics for Civil Servants of the Republic of Indonesia [14].

Then it was updated in Law Number 5 of 2014 concerning State Civil Apparatus, as well as in Regulation of the Minister for Empowerment of State Apparatus. In this context, although there are internal units such as the inspectorate that deal with issues of integrity, financial misappropriation and aspects of complaints from whistleblowers, according to the author, who has worked for 23 years in government agencies is not very effective because it still has the opportunity to create good patron-client relationships. strong between echelon I and II officials.

Third, considering that the current era demands that the government be accountable and transparent to the public, the Jokowi government must oblige all government agencies, both central and regional, to reactivate the existence of hotline communication channels that connect bureaucratic leaders with service users to obtain information rights. or submit complaints or complaints about problems not only to the leadership of the organization, but to the organization's Internal Ethics Committee/Council. This is as mandated in the Law on Public Services Number 25 of 2009 concerning Public Services [15] and Law of the Republic of Indonesia Number 14 of 2008 concerning Disclosure of Public Information [16].

\section{Conclusion}

Simplification of the bureaucracy by cutting the structural positions of echelon III and IV on the one hand has invited the popularity of the Jokowi government in the context of budget efficiency and effectiveness, cutting lengthy bureaucratic procedures and accelerating the decision-making process. However, it should be borne in mind that this policy of bureaucratic simplification deals with the patrimonial bureaucratic culture that is deeply entrenched in our government. Several studies on the culture of patrimonialism which require a reciprocal or reciprocal relationship that is mutually beneficial politically and economically prove that patrimonial culture is still deeply entrenched in our bureaucracy, especially in the reform era, especially in the Pilkada. at the central and regional levels.

In line with this problem, there are several strategies that the Jokowi government can take in order to reduce the patrimonial bureaucratic culture in various ways, starting from enforcing a massive merit system policy in all government agencies both at the center and in the regions, forming 
ethics committee boards at all levels of government and encouraging transparency in publications or in open complaints against any violation of regulations by both the central and regional governments so as to provide space for the public to openly control the performance of the Jokowi government.

\section{References}

[1] Gerth, H.H. and Wright Mills, C. 1977. From Max Weber: Essays in Sociology. London and Boston: Routledge \& Kegan Paul

[2] Brown, David. 1994. The State and Ethnic Politics in South East Asia. London and New York: Routledge.

[3] Sukitman, T., \& Alam, S.M. (2015). Kekuasaan Patrimonial Politik Lokal: Relasi Patron-Klien Pada Pemilihan Kepala Desa Aeng Tong-tong Saronggi Sumenep.

[4] James C. Scott, 1972. Patron-Client Politics and Political Change in Southeast Asia. American Political Science Review, 1972, vol. 66, issue 1, 91-113

[5] Emmerson, D. K. (1983). Understanding the New Order: bureaucratic pluralism in Indonesia. Asian Survey, 23(11), 1220-1241.

[6] Dwiyanto, A. (2001). Budaya Paternalisme dalam Birokrasi Pelayanan Publik. Policy Brief, Center for Population and Policy Studies, UGM, Yogyakarta.

[7] Jati, W. R. (2012). Kultur Birokrasi Patrimonialisme dalam Pemerintah Provinsi Daerah Istimewa YOGYAKARTA. Pusat Kajian dan Pendidikan dan Pelatihan Aparatur III, National Institute of Public Administration Indonesia.

[8] Raestyawati, Umi, 2015 Karakteristik Birokrasi Lokal (Aristokrasi Jabatan Kepala Desa Di Desa Sumberejo, Kecamatan Kerjo, Kabupaten Karanganyar the Indonesian Journal of Public Administration. Volume 2 Nomor 1)

[9] Mario Tawaris, Jhonny Kalangi, Deysi Tampongangoy, 2018. Transparansi Mutasi Pegawai Pada Badan Kepegawaian Daerah Kabupaten Halmahera Utara. Jurnal administrasi publik. Volume 4. Nomor 61.

[10] Rusliandy, Heru Nurasa, Yogi Suprayogi Sugandhi, dan Ridwan Sutriadi.2019. Hambatan Implementasi Sistem Merit Pada Dinas PUPR Kabupaten Bogor. Dalam Pengelolaan Infrastruktur Jalan Kabupaten. Jurnal BKN. Volume 13. Nomor 1.

[11] Umbu Mette R.R 2018. Politik Kedde: Mobilisasi dan Patronase Birokrasi Dalam Pilkada di Kabupaten Sumba Barat Daya. Tesis program magister Sekolah Tinggi Pembangunan Masyarakat Desa APMD Yogyakarta.

[12] UU nomor 5 tahun 2014 tentang Aparatur Sipil Negara

[13] Peraturan Pemerintah Nomor 11 tahun 2017 tentang Manajemen PNS

[14] Peraturan Pemerintah Republik Indonesia Nomor 42 Tahun 2004 tentang Pembinaan Jiwa Korps dan Kode Etik pegawai Negeri Sipil Republik Indonesia.

[15] Undang-Undang Nomor25 Tahun 2009 tentang Pelayanan Publik,

[16] Undang undang Republik Indonesia Nomor 14 Tahun 2008 tentang Keterbukaan Informasi Publik 